\title{
Editorial Expression of Concern: Coincident locations of rupture nucleation during the 2019 Le Teil earthquake, France and maximum stress change from local cement quarrying
}

\author{
Vincenzo De Novellis (1D, Vincenzo Convertito, Sotiris Valkaniotis (1D, Francesco Casu (D), Riccardo Lanari, \\ Mario Fernando Monterroso Tobar (1) \& Nicola Alessandro Pino (1)
}

Addendum to: Communications Earth \& Environment https://doi.org/10.1038/s43247-020-00021-6, published online 18 September 2020.

The editors of Communications Earth \& Environment have been alerted that in this article, incorrect data were erroneously used to calculate the stress changes associated with cement quarrying. This error will affect the conclusions that can reliably be drawn. Communications Earth \& Environment is working with the authors to resolve the matter, but in the meantime, readers are cautioned against using results from this article. All authors agree with the publication of this note.

Published online: 22 October 2020

\footnotetext{
(c) (i) Open Access This article is licensed under a Creative Commons Attribution 4.0 International License, which permits use, sharing, adaptation, distribution and reproduction in any medium or format, as long as you give appropriate credit to the original author(s) and the source, provide a link to the Creative Commons license, and indicate if changes were made. The images or other third party material in this article are included in the article's Creative Commons license, unless indicated otherwise in a credit line to the material. If material is not included in the article's Creative Commons license and your intended use is not permitted by statutory regulation or exceeds the permitted use, you will need to obtain permission directly from the copyright holder. To view a copy of this license, visit http://creativecommons.org/licenses/by/4.0/.
}

(C) Springer Nature Limited 2020 